\title{
Teresa Łoś-Nowak
}

\section{INTERNATIONAL SPACE VS. INTERNATIONAL ENVIRONMENT: NEW PHENOMENA AND NEW CHALLENGES FOR POLAND'S FOREIGN POLICY}

DOI: $10.1515 /$ ppsr-2015-0011

\begin{abstract}
While analysing Poland's foreign policy and its dilemmas from the perspective of changes in the international environment at the turn of the 21st century, the Author introduces a new analytical category - "international space". This is a new analytical term with larger explanatory content and more capacious than the category of international environment. This paper explains the validity of such a procedure and its analytical strength. Against the significance of changes, it is the international space, not international environment, that is able to explain the depth of changes in morphology of the international system, where access to knowledge and information has become the source of changes and their dynamics. These phenomena and processes critical for the international system force the post-industrial country to develop a new approach to Poland's foreign policy. They also impose reflection on Poland's presence in the global "post-modern" international space, segments of international relations that are important for its development. This paper should be treated as an introduction to the difficult but very important debate on Poland's foreign policy, dilemmas that it has to face, and areas of special sensitivity for the state and its development.
\end{abstract}

Keywords: Polish foreign policy, globalisation, international space, networks, global governance.

\section{Introduction}

In the science of international relations, "international environment" constitutes one of the key issues in close connection with the state and its relations with the closer and further environment. Research on this phenomenon has had a long history. I do not want to develop this topic, as there are many interesting studies on it. As an example, let me mention Aristotle and his social theory of indissoluble relations between man and environment, J. Bodin, J. Montesquieu, and other classics. In the 19th century, F. Ratzel and K. Haushofer exposed geographical determinism constituting the synthesis of anthropology and politics. In addition, in his studies about the state, Alfred T. Mahn has discerned the sources of success in foreign policy regarding location at the seaside, coastal character, length of the coastline, and physical parameters, etc. In his theory of advantageous geographical space, J. Mackinder exemplified the continental position of the state (Dougherty \& Pfaltzgraff 1997, 144-178). Next to geographical determinants, modern researchers, such as Harold and Margaret Sprout, A. Giddens, and Q. Wright, have started to pay greater attention to other prerequisites of welfare, success of state foreign policy, and strengthening a state's global position: inter alia the accessibility of resources, easy transport, the relation of the state to the international environment, and 
the scale of its interactivity (Sprout \& Sprout 1957, 309-328; Cohen 1963; Wright 1965; Giddens 2008; Keohane \& Nye 1977). In the second half of the 20th century, the end of the Cold War, particularly globalisation, the cross-border factor, and interdependence generally caused the international environment to lose its clarity characteristic for the bipolar world, Westphalian system, and governance mechanisms of the "closed world". As R. Kuźniar writes: "It lost its almost homogenous character and almost geometrical clarity of the Cold War epoch" (Kuźniar 2005, 274-5). New, but very influential competitors of sovereign countries emerged (international non-governmental and transnational organisations), transnational classes of managers, corporate elites, and broadly defined social movements were established. Transnational organisations of civil society became their symbol, while the "network", i.e., a network of relations, a "chain of understanding and common aiming", became their basic organisational form (Panas 2013; Dumała 2010). The information revolution and other dependent variables changed the spatial image of the world "related to orthodox ways of perceiving the space and environment (...)" (Gałganek $1989,106)$, redefining the meaning of geographical position and territory as the source of a sovereign's power, "time" as the symbol of globalisation "compression" of space, and the sign of new temporariness of international contacts. Thereby, the prerequisites reappeared to return to a discussion on the international environment creating the framework for a state's external activity, understanding its physicality, but also to the need of cognising an emerging new spatial image of the post-industrial world (Zacher 2006). Transformations of the spatial structure that we observe express the decomposition of the Westphalian system and the need of getting to know phenomena and processes announcing its new dimension. In their visionary study titled Creating a New Civilisation: The Politics of the Third Wave, Alvin and Heidi Toffler say that "before our eyes, new civilisation is emerging in our life", while humanity, although not aware of it yet, "faces the deepest social revolution and the boldest creative transformation in its history" (Toffler \& Toffler 1996; Muszyński 2001). Therefore, it is not an accident that it seems to be purposeful to reach other categories, such as international space and a spatial image of the world, to show the depth of changes occurring in the international environment at the turn of the 21st century.

In classic understanding of this term for the international environment, values of geographical position, accessibility of resources, quality of external borders, easy transport, etc., still constitute important determinants of the state's attractiveness. However, international space, which expresses a non-linear character of geography, a new organisational form of society and the post-industrial state, new forms of production and trade, and communication forces its conceptualisation, thereby constituting a new analytical perspective in the science of international relations.

As it was mentioned above, the decay of the bipolar world has affected processes of reinterpreting the significance of the environment for the state and its place in the international system. The construction of a "closed world" or "binary" analytical perspective creating the framework for international relations in conditions of the postindustrial world is not able to explain the evolution of the international system that has occurred in the last 50 years. The emergence of the post-industrial society, processes of internationalisation of national economies, the establishment of global financial markets, 
and deeply developed informationism force a new approach to the state and its surrounding, in which success is measured far more by access to knowledge and information, as well as by presence in international institutionalised spatial structures expressing the process of deep reconstruction of the current political, economic, and social order at the global level, than by geophysical parameters. For the world in the future, the previous model of the international system and the way of its organisation seems to be "too static". Therefore, one should agree with B. Barber and his thesis from the beginning of the 20th century that "today's world leaves rapidly and arrives uncertainly at the same moment" (Kaufmann 1997, 174). That is why capturing this moment when "old" world gives way to the new one is so important for the state. Globalisation, the cross-border character of interactions among various subjects of international relations, and deepening interdependence change the spatial borders of the world. They show distinctly that its new image is related not only to expansion of markets, trade, and capital at the global level, but also to global information constellation forcing "transformation" from (modern) national states to (post-modern) network states (Stalder 2012, 141). The criterion of differentiation of the international space in the 21 st century " (...) has become the amount of capital representing given areas", presence in spatial international structures, and the ability of shaping them (Gałganek 1989, 106-107). This is a significant diagnosis of the international system and a premise for the state, as the post-industrial international space and emerging new spatial image of the world are forcing a new type of international relations (inter-state, transnational, and cross-border). They are also constructing a new type of society and state, as well as defining their specificity and forms of manifestation. Therefore, one may propose the following thesis: against the significance of changes occurring in the post-Westphalian system, a new look at the environment in which the post-industrial state exists and functions may show and explain changes in the morphology of the international system deeper than the orthodox approach to the international environment does. The "international space" perceived in this theoretical perspective constitutes the material base for "network" organisation of the post-industrial society, where the global market, global production, progressive integration, and fragmentation of the geographical space and politics occur. Therefore, the introduced term "international space" seems to be more comprehensive to correspond with the depth and essence of changes in the international system, their power, diversity, variability, discontinuity, complexity, variety, multi-level, and emergence. As an analytical category, it seems to be an important research tool to explain developmental megatrends of the post-modern world (Muszyński 2001). As J. Potulski says, it requires a "completely new research approach and development of totally new research categories" (Potulski 2010, 31). Reconstruction of the post-modern world's international space may be conducted through deconstruction of the world following "Westphalia" and through deep changes in the international system, its structural, and functional features, as well as attributes of its participants and the character of relations among them. The Westphalian model of the global order becomes a relic of the past, but "Westphalia" treated as a symbolic metaphor of the new international order "(...) may be useful at anticipating a post-modern global future (...)" (Gałganek 2008, 53), just like in the process of reconceptualisation of power and international space. 


\section{International space}

It is very hard to define the international space of the post-modern phase (in its political, economic and socio-cultural dimension). Nevertheless, its specificity, new subjects functioning in this space, new rules of behaviour, new policy-making philosophy, and, first of all, the specific symmetry among various spheres of social life (especially among spheres of politics, economics, culture, and the creation of world media) can be brought out. In my understanding of the essence of changes in the international system, the international space of the post-modern world is the whole of relations occurring in the international environment among its various subjects/participants. They create it. It expresses a new quality and character of the organisation of the international system, structure of relations and dependencies, and mechanisms of acting in more and more network relations, dependency among them, and their intensity. As international cooperation gets more dynamic, new areas of cross-border, regional or global cooperation emerge. Complex mechanisms of institutional structures managing the globalising economy, trade, finance, and cultural and civilisational relations, come into being. In this process, a new international space emerges, which we do not know - the creation of the post-industrial society and a symbol of global transformation. If the state is to perform the functions assigned to it and demonstrate its timeless value, it must be integrated with various dimensions of the international space.

M. Castells, the author of the trilogy The Information Age: Economy, Society, and Culture, regards the international space as a "historically conditioned social form, the significance of which comes from social processes that express themselves through it". As he emphasises, space as a social product is a dynamic category. It signals interactive approaches among subjects, “(...) especially connections among various sets of social structure: connections of economic, political, and ideological systems, as well as particular features of social relations resulting from them (lder 2012, 166-167). L. Moczulski perceives "space" differently. In his study titled Geopolitics - Power in Time and Space, he mentions "invariable geographical space", which is a "mirror" illustrating "both variable historical structures and their syntheses" (Moczulski 1999, 317). L. Moczulski understands space synonymously with the notion of geographical environment with a deterministic significance in human development. Undoubtedly, such an approach has played an important role in the life of states, nations, and individuals. However, it is not the only factor able to explain the phenomena of social, political, and economic life in the historical space, especially in its modern version. Nowadays, there are many of these factors in actual physical space and they are more diverse in the area of their impact on a country's condition. Moreover, their significance changes together with social, civilisational, and cultural changes. In consequence, the international space and the way of its development are changing.

Modern understanding of international space differs from the traditional perception of its scope, structure, and character of relations among subjects operating in it. This change is among others a consequence of deep modifications in the international system, the way of its organisation, international environment, and functional mechanisms. Their 
primary media include globalisation, interdependence, and cross-borderism. This is not only signum temporis of the post-industrial society, but also a driving force of its new organisation. They are expressed by de-territorialisation and "decompression" of time and international space. "Coincidence" ${ }^{1}$ is more and more often discussed because of the decompression of these two values changing quite radically the way of "managing" international space, particularly the possibility of its use to develop a country's potential and its position in global politics, economy, and culture. Here, the attractive thesis "about the end of Gutenberg's epoch" becomes a symbol due to the latest achievements in communication technology. Undoubtedly, it forces a new look at space, in which the geographical environment is one of many factors explaining complex social processes.

The modern political, economic, and informational international reality, affected significantly by globalisation processes, implicates its different organisational framework, different principles of actions, different standards and rules of proceeding of actors/ participants of international relations, new contradictions, and crises. In this apprehension, space is a "material support for modern social practices. (...) It connects practices, which are simultaneous" (Castells 2011, 436), indicating new sources of power in the international system. It is an important sign of the times, as power in the 21st century is characterised by "(...) dispersion, decentralisation, and at the same time - ubiquity", while the state needs to change the strategy of behaviours to develop itself, extending the field of cooperation in the global network of economic, financial, and informational processes, etc. Until recently, power has been discretionally assigned to a sovereign state, while today it is being limited (shared) with other subjects. It concerns all areas of its perpetration: economics, politics, safety, and culture. Even control over means of violence goes to other actors rather than states (Kuźniar 2005, 266; Uesseler 2008), as cyberspace, i.e., "space of open communication through connected computers and IT memories operating all over the world" (Lakomy 2010, 56), will constitute the future battlefield.

Countries omitted by global flows of richness and possibilities, unable to understand the depth of changes in the world, can at last persist in stagnation. The key is constituted by knowledge about the significance of changes in the post-modern epoch's international environment, as well as by "spatial imagination" of the occurring changes, directions, and tendencies they undergo, and openness for changes. "Spatial imagination" is important not only for an architect and town-planning specialist, but for a politician, researcher, strategist, and expert. As a "product of the post-industrial society", it:

- is a symbol/synonym of deep transformation in the development of a new material base of economy, trade, and production organisation at the global level

1 The term "coincidence" created by M. Castells symbolises deep changes in the development of capitalist economy, human relations, and exchange of thoughts, etc. - phenomena occurring in the international space. However, this is a new type of international space, in which various social (economic) actors may be in the same temporal space without being in the same physical space (the Internet, network flows). For this process, it is more important that key social or economic institutions are restructured in a way that allows them to draw benefits from this, gaining a competitive advantage over those who are loyal to the conventional logic of space-time, and thereby (through the network logic) becoming incompatible with these actors. 
- defines new types of economic, political, and cultural relations and systems, different that those valid in the preceding industrial phase of civilisational and organisational development (the society of risk)

- is simultaneously a source and a consequence of the dynamics of organisational, political, and economic, i.e., generally civilisational, changes in the international system

- also connects a different understanding of power in the international environment, its different sources, and the way of performance. It is a sign of a process known as transformation of power relations in the international system (Stalder 2012, 124)

\section{Power in the international space of the post-modern phase}

The world at the turn of the 21st century "experiences deep qualitative changes related to technological revolution in the communication sphere, expansive development of modern social formation (...), and to deepening and accelerating processes of development of global joint connections in all areas of life" (Potulski 2010, 55). These changes symbolise the process of emerging new sources of power in the international system, new forms of their use, performance, and often - new subjects. We may call this process a transformation of power relations in the international system. As M. Castells writes, in it we have to do with transformation of national states from "sovereign subjects to strategic actors" (Stalder 2012, 124) confronted with reality. In this reality, quickly developing "supraterritorial institutions and social organisations having common standards and interests" and capacity of co-deciding in international politics at various levels of its manifestation has become important co-participants of decision-making processes. They create a "new geopolitical reality consisting of eclectic networks of power centres connected with each other (...)" (Potulski 2010, 65), which seem to be impossible to omit.

In conditions of deep transformation of the international economy, expansion of new communication systems, direct transfer of information and human intellectual potential, and exclusivity of the state in performance of its power over a territory and population becomes weaker. The tools applied to do this are changing. Due to globalisation, cross-borderism, and correlation, the limitation of the state's authority to a territory in a geographical sense becomes less attractive as a source of successes and welfare. Active presence of the state in the international space, cognition of the significance of the changes it undergoes, skilful use of instruments offered by supranational and transnational institutions, and the availability of information and knowledge become more important. In the 21st century, the value of geographical space as a stake in competition for power in the international system has been changing. It is easy to perceive "that international decision-making environment has been extended, fragmented. New structures are appearing, creating the space of activity for diverse stakeholders absent in this sphere" (Zachara 2012, 67-69). These new actors and the relations between them and the state - in the reality of modernly occurring transformation of the international system and power relations in this system - create the international space, its new organisational forms, and its mechanisms of operation. 
"Globalisation means that game of power begins. Rules and basic terms of the former game lose their meaning in it (...). Together with globalisation, a new space of operations and new framework of activity are formed: politics derives from borders and states, so additional players, new roles, new resources, unknown rules, new contradictions and conflicts appear" (Beck 2005, 23). Enterprises and transnational corporations reach for power in the international environment. New corporate elite draws new power centres. Next to them, the "game" in global politics is joined (yet shyly and with variable results) by transnational subjects expressing the needs and interests of international society, political parties, and finally of much more aggressive terrorist and criminal organisations. In the global dimension, a "(...) slow transformation of international power system based mainly on states and initiatives constituting configurations of state involvement in the global system, engaging all subjects affecting strategic areas of the world" (Zachara 2012, 26) becomes the reality. Therefore, entering "the age of information", shaping of "the society of knowledge" and "internationalisation" of national economies recreate prerequisites to a discussion on a new organisational framework of international space, new power manifestations, and environmental determinants of state foreign policy. In the postWestphalian international system, old rules of behaviour are changing and the new reality forces a new/different philosophy of politics on the state.

According to some researchers, while entering the post-modern international system, the state as a political and social institution does not work, as the post-modern world needs new mechanisms of global governance, new forms of cooperation, and new strategies (Barber 2013; Albrow 1997). However, it does not mean that it is redundant, just the opposite (Łoś-Nowak 1997, 79-96; Łoś-Nowak 2009, 17-42). Previously formulated theses emphasise that its presence in the international system makes its attractiveness and specific timelessness credible (Strange 2003). The world without states cannot be excluded, but it is still a distant and rather unclear perspective (Nakonieczna 2005, 601). One may agree with theses of the cosmopolitan vision of the international system that the Westphalian formula of the national state has become too tight in the age of global connections to build a new order and new rules of the game in the world of politics (Pogge 2002; Żukowski 2009; Baran 1992). Even the followers of the realistic paradigm, in which the state still occupies an important place in the hierarchy of international relations' subjects, do not question this. Even when they see that its significance is declining, it decreases in some areas of activity, while in other areas its functions and capacity of steering processes increase in a direction they want (Webber \& Smith 2002, 16; Giddens 1990). Undoubtedly, the state's attractiveness decline when it is on the margin of the global economy, omitted by global flows of richness and possibilities. Such peripheral states can at last stagnate and gradually decay. One of the disadvantages of globalisation is its more and more visible asymmetry in division of economic benefits of global growth through a significant part of states with "localised" economies - economies "functioning on the margin" or "on borders of dynamics and changes in modern civilisation" (Pietraś 2002, 65). 


\section{Poland's foreign policy in the international space at the turn of the 21st century: tendencies, priorities, and strategies}

Surprisingly significant changes in the international space in the last 50 years in structures symbolising the global economy, the globalising market of international finance, and new governance mechanisms pose challenges and problems to Poland. Decision-makers responsible for its security, development, and position in the international system are open to challenges and ready to bear the risk that is always related to politics - they need to respond rationally to these challenges and problems. Is the Polish elite ready for these challenges? Is Poland present in the global "post-modern" international space? In which segments of international relations does it participate in significantly - in the process of economic, scientific exchange, security, culture, and decision-making groups with global reach?

There are many questions and problems connected with the global transformation of the international system and with Polish strategy of taking part in this process. It is difficult to answer them substantially and deeply, considering limitations imposed by the formula of this paper. Therefore, this study should be treated as introduction to the difficult but very important debate on Poland's foreign policy, dilemmas that it has to face and areas of special sensitivity for the state and its development.

\section{$* * * * * * * * *$}

Due to its geopolitical position at the heart of Europe, the Republic of Poland "is a natural meeting and dialogue place for three parts of former Eastern Europe, including the German-language region, the Danubian-Balcanic region, and former lands of the Commonwealth of Poland" (Bielen 2007, 20). On the other hand, due to an active and visionary developed strategy against closer and further surroundings, the geographical position of Poland at the "heart" of the continent may become "Cassal's node" in global networks organising economy, trade, exchange, and politics on a global level. Today, when we think that we have a stable international position, the centre of a particular interest for politics, politicians, experts, and decision-makers able to think with perspective should be constituted by the following segments of the international space:

- political space - arena of deconstruction of the former order, new threats and challenges

- economic space - symbol of processes of internationalisation of economy, production, trade, and information

- institutional space expressing new global governance forms

- cultural and civilisational space

\section{Political space - an arena of deconstruction of the former order, new threats, challenges, and dilemmas of Poland's foreign policy}

At the turn of the 21st century, the world became more chaotic and non-instantiated in its construction, and thus difficult to embrace. Disintegration of the bipolar system and decay of one of the pillars opened a new stage in the history of international relations. 
The concept of unipolarity forced by Z. Brzeziński and Ch. Krauthammer appeared on the market of projections of the international order. It was accompanied by the nonhardened world of Huntington's concept of unipolar multipolarity, Kissinger's concept of a multi-polar world with the US as the strongest of a group of several superpowers, but equal among equals (Łoś-Nowak 2005, 21; Jarczewska-Romaniuk 2005, 227; Menkiszak 2005, 275). In President B. Obama's concepts of the US, the formula of "the partnership of the US and China" and "the partnership of the EU and US" has appeared as the basis of a new global order. They sound interesting, but they have all caused a harsh response by Russian politicians, who reject the idea of Russia irrecoverably loosing its position of superpower. Moreover, new Asian powers (such as China and India) and "emerging" empires from South America (Brazil and Argentina) have appeared on the political scene. They are ready to participate in the global international order. Ironically, at the same time Europe has started to lose its special economic-strategic and scientific-technical position in favour of Asia and its new superpowers. New divisions and alliances have replaced old ones. Formerly established political, military, economic, and cultural strategies have been collapsing. This process has not omitted Poland.

After the fall of the Communist Bloc and the dissolution of the Soviet Union, Poland commenced the process of establishing new bonds and a new type of relations with closer and further surroundings, including Western countries, with which political, economic, and military contacts were limited due to ideological reasons. They were slowly becoming a real fragment of international space of Poland and other countries from former Eastern bloc. Membership in NATO and the EU caused that "(...) it was in new system of geopolitical interdependencies, in which neighbourly relations overlap with allied correlations and consolidation resulting from a high level of integration" (Bieleń \& Skrzypek 2012, 7). In that new geopolitical reality, several important questions had to be answered: first, where is Poland in this confusion of interests in a so far unstable global policy scene? Second, who should be its strategically important partner in foreign policy? Finally, what strategy should be chosen to secure the interests, needs, and rations of the Republic of Poland?

Regarding the ontic dimension of the international environment, in which Poland was after 1989, the question about subjects of international relations, symbols, and media of evolutionary changes in the international space at the global level was essential for its international position, broadly understood security, and international cooperation, etc. Countries with superpower status were regarded as the most important, just like states aspiring to such a status and those that were beginning the fight for restoration of their place in the international system's structure appropriate for global superpowers after periods of weakness. A system of relations among them, developed networks of political arrangements, and connections became a significant component of the foreign policy concept and developed strategies of behaviour in the political international space for medium-sized states, such as Poland. Security, growth, and the possibility of coparticipation in global politics were the stake in that game (Ministry of Foreign Affairs of Poland 2011, 5).

The US and Russia started to become actors with an important position in Poland's foreign policy and in its future, each of them for different reasons. "Close relations with the 
United States are one of the strongest advantages that our foreign policy has at its disposal" - said Minister W. Bartoszewski in the Sejm in 2001(Ministry of Foreign Affairs of Poland 2011, pp. 234-235). In his speech in the Sejm in January 2003, Minister W. Cimoszewicz confirmed former declaration, saying that: "In relations with the United States, we aim at strengthening mature strategic partnership, supporting the dynamics of political and military relations" (Ministry of Foreign Affairs of Poland 2011, 273). Polish-Russian relations have been more difficult. They are burdened with "ghosts of the past", stereotypes and mutual fears (Ministry of Foreign Affairs of Poland 2011, 278), regardless of the fact that "Poland and Russia have been united by significant potential of ethnic, historic and cultural closeness" (Ministry of Foreign Affairs of Poland 2011, 339). The dynamics and level of Polish-Russian and Polish-American relations, mainly their quality, is still an open problem. This seems to result from the quality and dynamics of relations of the US with Russia and other countries that are particularly important for all these three states. PolishAmerican relations and Poland's foreign policy towards the US are often interpreted by Russian diplomacy as an argument about instability and the lack of transparency in Poland's strategic priorities and strategic partners, etc. ${ }^{2}$ Poland's foreign policy towards Ukraine, especially its support for Ukrainian aspirations to EU membership, is inscribed in Polish-Russian relations. Russia is doing everything to counteract this policy and limit Polish activity within this scope, not avoiding blackmail and economic and psychological pressure (Ministry of Foreign Affairs of Poland 2011, 447).

Poland's accession to NATO and the EU meant not only a partial change in the EU's policy towards Russia and CIS countries, but also a gradual resignation from conducting a completely autonomous Polish Eastern policy for the benefit of its "communitisation", which does not facilitate mutual Polish-Russian relations. The Eastern Partnership and European Neighbourhood Policy, established in 2003, are an example. They change not only the geopolitical value of the region for Europe, but also for Russia. Relations and common initiatives developed in this new space create a new quality in this sub-regional system. They constitute the sign of new bonds, through which rations and interests its creators realise their interests and dreams. Several weeks ago, Minister R. Sikorski was speaking in the Sejm of Poland and exposed the sense of Polish involvement in the support of Ukrainian efforts (as well as Georgian, Armenian, and Azerbaijani) for integration with the EU. In the Sejm exposé of March 2013, in its fragment addressed directly to Ukraine, he referred to dilemmas of choice faced by the country, indicating two essential political and social threads strongly affecting the decisions soon to be made. Former experience of relations with Russia is the first; and the second includes various models of civilisational development, which Ukraine needs to face, being aware of the complexity of a situation in the present geopolitical and geoeconomic reality. Minister R. Sikorski declared the openness and willingness of cooperation on behalf of the Polish government. However, he did not hide the fact that the pace and efficiency of this cooperation, as well as the European political space to be more broadly open to democracy, human rights, and law-

${ }^{2}$ For example, Russia used the US announcement of locating an anti-missile shield in Poland and Poland's position in this matter. 
abidingness, will depend on "what civilisational membership nations of the Eastern part of the continent will choose" (Ministry of Foreign Affairs of Poland 2013).

Essentially, the challenge for Poland (the EU and the international community) in the 21st century, as well as a real threat, is constituted not by the political and economic consolidation of Russia, but by its creation of the alternative model of socio-political development on the territory of the former Soviet republics. In connection with the offer of technical, economic, and military support, and currently blackmail and the use of economic-financial pressure against countries of the Eastern Europe and Middle Asia, it is a dangerous tendency, clearly oriented towards destabilisation in the region. It puts Poland in a difficult situation, as it does not have the instruments to hamper implementation of this strategy by Russia (Ministry of Foreign Affairs of Poland 2011, 447). Polish-Russian relations are also inscribed in the context of Poland's foreign policy towards Ukraine (Tymanowski 2009). A new strategic approach to Russia and its political-economic strategy seems to be necessary against non-best Polish-Russian relations. The most obvious evidence seems to be another attempt of using economic and political factors as a means of pressure on Poland and its approach towards Ukrainian aspirations to join the EU immediately before Ukraine and the EU were to sign the Association Agreement.

As Poland's strategic partner frequently exposed in statements of subsequent ministers of foreign affairs, the US seemed to withdraw slowly from Europe and its problems related to the security policy developed under CFSP, the EU and NATO. Thus, it moves the centroid in foreign policy to the region of Central and Eastern Asia, perceiving the growth and aspiration of China to superpower status as a threat to its global position. In the context of the foreign policy of the US, which is struggling with internal problems and international policy, it seems that more and more often we start to understand that sympathy for Poland and for the Polish nation manifested by President B. Obama's administration is significant, but in a declarative sphere. A fragment of Minister Sikorski's statement addressed directly to that ally is symptomatic in this context. "We are happy - the Polish Minister of Foreign Affairs says - that the USA recalls its old European friends despite interests in other parts of the world" (Ministry of Foreign Affairs of Poland 2013). Essentially, Poland is too weak to be a strategic partner of the US due to its potential and global position. It is hard to expect that it will soon be perceived by the US as a key player. China and, still, Russia become such, despite important differences between them concerning significant strategic issues (Syria). In addition, the EU and European NATO countries do not treat Poland as a key player in the EU.

Due to the complicated character of geopolitical interdependencies in Europe, where neighbourly relations started to overlap allied interdependencies, Poland needs to develop a reasonable model of foreign policy, in which its national interest will not be a derivative of the reasons and interests of its partners from the EU and NATO (Bielen \& Skrzypek $2012,7)$. Another strategy may lead to its marginalisation, not only on a global level. Minister Siemoniak spoke about that in the interview dated 14 August 2013, drawing attention to the increased military presence of the US in the Asia-Pacific region. Poland a "border country" in NATO - should remember this (Siemoniak 2013). 


\section{Economic space - a symbol of internationalisation processes of economy, production, trade, and information}

Experiences from last 200 years of global economic development demonstrate even too clearly that creation and then development of national economies and differences at the level of economic growth between particular groups of countries and regions was “(...) in time coincidence with the process of global economy development" (Rewizorski 2011, 62). Nowadays, we perceive this rule even more harshly, analysing the competitiveness of national economies of highly developed, developed, and developing countries on the global market (Polak 2009, 82). In developed countries "with knowledge-based economy founded on production, distribution and practical use of knowledge and information with application of the latest technologies" (Polak 2009, 61), differences in dynamics of economic development against countries of prevailing traditional economy are drastically multiplied to the disadvantage of the latter, often objectifying them. Global economy, finance, informatisation, international networks and flows, information and knowledge, "internationalisation" of economy, production, and financial markets become a specific logo of the international system. They situate the state in the position of active "player", grants it subjectivity, and opens the capacity of participating in international decisionmaking structures, which are important in post-industrial economic space - symbols of power and status in the international environment (Ministry of Foreign Affairs of Poland 2013). ${ }^{3}$ This regularity seems to determine the strategy of states, including Poland, in the economic space of the post-industrial world. Minister Sikorski talked about that regularity in the Sejm, while presenting the foreign policy for 2013. "When capitalism was born in modern Europe, we were aside. The first manufacturing in Western Europe was established in the 13th century, while in Poland - at the end of the 16th century (...). Before the Great Sejm, in 1788, Polish GDP decreased to the level of only $16 \%$ of British GDP (...)" (Ministry of Foreign Affairs of Poland 2013).

This reference to the past does not seem to be accidental. History teaches us that the state is "condemned" to slow marginalisation when it "stays" in opposition to main developmental tendencies in international policy, distances against changes in the international environment, or does not notice symptoms of changes or main trends. Finally, it means its weakening position and disability to provide society with secure development.

According to World Bank (a leading organisation of global economy) criteria, Poland's current position in the global economy situates it in the group of 40 states with higher income per resident than average (34,660 euros - 10,725 dollars), next to the Czech Republic, Hungary, Russia, Malaysia, and Turkey. In turn, according to IMF classification based on comparison of a state's potential (national income, export, amount of monetary reserve), Poland occupies the 32nd position in the world. In addition, dynamic factors related to the growth rate demonstrate Poland's position in the global economy system.

${ }^{3}$ In the case of Poland, this regularity may be read in data concerning the Polish economy in different periods of development (GDP per capita from the 11th century to modernity, GDP per capita of Poland and selected countries from the 11th century to modernity, global GDP of Poland and selected European countries from the 11th century to modernity, and other data). 
They are beneficial. Since the turn of the 21st century, Poland has belonged to a small group of European and world countries, which note systematic economic growth. Although recently it has been significantly slower, the national economy has not experienced recession and economic breakdown. The forecasts seem to be optimistic. Minister Sikorski presented information on tasks of Poland's foreign policy in 2013 in the Sejm, quoting indicators to demonstrate the successes of the Polish economy in the last 20 years and positive developmental trends included in the above-mentioned IMF and World Bank (Ministry of Foreign Affairs of Poland 2013).

This generally positive image of the Polish economy and dynamics have become possible due to integration with the EU and closer cooperation with international and transnational economic, financial, and trade organisations, as well as increasing competitiveness of the national economy, Polish enterprises, and innovativeness. This means that Poland's strategy of "becoming involved" in cross-border and the global economy and trade - with awareness of the existing asymmetry of potentials compared to the largest economies of modern countries - is a non-alternative strategy for a country such as Poland (Ministry of Foreign Affairs of Poland 2013). However, it needs to be formulated by the state's institution with respect to relatively bilateral autonomy. When modern countries have no capacity of action, co-participation in processes of control over the national economy, flow of finance, information, and culture, they are marginalising themselves as important economic, financial, and political subjects.

\section{Institutional space - a symbol of progressive institutionalisation of international cooperation and new global governance forms}

A measurable confirmation of the openness of national economies for processes occurring in the economy, trade, and finance is constituted by presence in international organisations, especially those with global reach in strategically important areas (economy, trade, and finance) and high intensity of relations with external environment. It also concerns transnational corporations - symbols of corporate globalisation. Transnational organisations of civil society constitute a new quality in the process of extending the field of participants of international relations with defined identity and capacity of conscious participation in international policy. Their presence and the way of functioning symbolise a prevalent tendency in the subjective evolution of the international environment, stimulating processes of the transformation of power relations at the level of the international system, and new sources and forms of power occurring in the international space (Marzęda 2006, 33). They populate international political, economic, financial, and cultural-civilisational space at the global and regional-continental level. They change principles and organisational forms of the international space, fluently going from interactive forms of cooperation to their multi-layered, network organisation. Their presence and the way of functioning symbolise a prevalent tendency in the subjective evolution of the international environment, stimulating a megatrend unknown in the past. A process of transformation of power relations at the level of the international system, quite contractually defined as "global governance", becomes their symbol. 
Today, the observed transformation of power relations at the level of the international system is an unusually important component of evolution occurring in the international system and one of the main tendencies of change in the international environment. They correspond to the new and complicated system of relations connecting various actors of international relations. The presence of states in it and the possibility of management of the international space understood in such a way are a "pass" to international and transnational institutions often deciding on a country's international successes, the scale of its security and welfare. Today, membership in these structures has become "the way the past reaches for the present day, and the resource to build the future" (Castells cited by Stalder 2012, 167). "The world is not only the world of states, but also the multi-level social world - an international community consisting of many actors" (Dumała \& Dumała 2012, 15). In relation to this megatrend of the 21st century, we may risk the following thesis: the network non-compatibility of a state in the international environment under the strong influence of developmental megatrends becomes a source of its weakness and limited capacity, inside and outside. Territorial expansion is no longer possible, wars become more and more expensive - they are being privatised. Therefore, "strengthening the country's position as a node of global economic networks" (Stalder 2012, 126) becomes the only preferred way to stimulate economic growth.

The "space of flows" of economy, trade, finance, culture, symbolising the new logic of international cooperation, the way of its organisation, new infrastructure used by diverse participants and economic, financial organisations, social entities, become the symbol of the "network" organisation of international life. As H. Dumała $(2012,181)$ writes, networks have always been present. The 21st century has only exposed their special sense, specificity, dynamics, and value. It consists of the fact that "networks developed by technology penetrate our life so much that a network has become a central metaphor, around which our thinking, social and political life, and economy are organised".

Therefore, it should be assumed that measurable benefits in strengthening Poland's international position can be achieved due to its more active involvement in the global economy, structures and symbols of modern institutional solutions, developed commercial and capital relations, and the extension of the size and scope of international flows (of people, goods, services, capital, and cultural assets) (Dumała 2012, 181). Limitations forced by convention of this paper do not allow for a detailed presentation of Poland's activity on international economic and financial markets, membership in decision-making centres related to enterprises, manufacturing and trade centres dispersed in various corners of the world, and the efficiency in attracting investment capital, transnational corporations, and direct foreign investments to its territory. It is estimated that approx. 65,000 international and transnational corporations operated in 2007 (in 1969, that number was 7,000). They had more than 900,000 branches and subsidiaries all over the world. The annual income of the largest 200 corporations comes to 18 billion dollars, while their assets are equal to 65 billion dollars (the capital of France $=1.5$ billion dollars). Seventy per cent of global trade, $80 \%$ of foreign direct investment (FDI), and $30 \%$ of global production is assigned to the largest 500 corporations. Transactions between corporations constitute one-third of global trade. They hire 60 million employees (Niemiec 2008, 128). This fact cannot be 
ignored. One cannot be distanced from the potential and possibilities given by investments of transnational corporations in the country and participation in international trade, economy, and international decision-making centres. Despite limitations, the acceptance of specific solutions or conducting concrete economic reforms imposed by transnational corporations and international organisations such as the WB, IMF, WTO and EU, countries are outdoing one another to attract foreign productive and financial capital, and to create the most beneficial conditions for it. ${ }^{4}$ Currently, more than 140 countries, including Poland, have signed Article VIII of the statute of the IMF, thereby expressing the consent to provide free movement of capital within the framework of current turnover transactions. In addition, the status of an FDI receiver is favourable for economic growth. According to UNCTAD data, $77 \%$ of global income stream has only been directed to ten countries in the world, giving the sum of USD 980 billion dollars. Ten per cent of FDI has been assigned to the remaining 180 countries. The same ten states have invested $69.2 \%$ capital in selected markets, in the form of direct investments. In the case of the CentralEastern European countries, they managed to obtain 260 billion dollars in 1999-2004. The year 2002 was a record in this regard, as 31 billion dollars was credited to states of the region, which constituted $4.6 \%$ of all global investment flows. It is not much, but the fact that Poland is still in the group of leaders in attracting FDI, next to the Czech Republic, Hungary, Russia, and Slovakia, is symptomatic. However, since 2000 its attractiveness has decreased (from 58\% in 2000 to 33\% in 2004), which is related to an increased interest of international investors in Lithuania, Latvia, Estonia, Slovakia, and Slovenia (Niemiec 2008, 146).

To finish considerations concerning global tendencies of the evolution of Poland's international environment, it should be emphasised that there is a great potential to develop an active economic and commercial policy at the global and regional level due to the favourable position on the map of international flows, its geographical and geopolitical assets, and the significant mobility and flexibility of Polish enterprises' operations on European and global markets. This positive image may be slightly modified by a low assessment of the attitude to foreign capital and the level of economic freedom and competitiveness by opinion-forming transnational corporations. ${ }^{5}$ Meanwhile, the process of internationalisation of national economies, development of global financial markets, and establishment of new forms of work organisation exceeding the national country's borders are in progress. Therefore, Poland should prevent the marginalisation of its presence in international and transnational economy structures. It should participate in decision-making centres related to enterprises dispersed in various corners of the world, manufacturing and trade centres, and care about attracting the investment capital of transnational corporations and foreign investments on its territory.

\footnotetext{
${ }^{4}$ In Poland, state aid has been used by approx. 140 enterprises, including IBM, Volvo, Philips, HewlettPackard, Korean LG (140 million zlotys), and Japanese Sharp (160 million zlotys).

5 In 2004, Poland was assessed as the fourth after China, the US, and Mexico regarding competitiveness. However, in 2007, it was in the group of so-called globalisation marauders. The Czech Republic, Slovakia, and Estonia received the status of top of the class. Data after: Wprost, 5 October 2003 and 27 January 2008.
} 


\section{Cultural space/soft diplomacy}

The second half of the 20th century, the end of the Cold War, and, primarily, globalisation, cross-borderism, and interdependence, have led to the loss of clarity of the international environment. This clarity characterised the bipolar world, Westphalian order, and the mechanisms of the managing of the "closed world". Non-territorial, very influential international non-governmental and transnational organisations have emerged as competitors of sovereign states. Additionally, transnational classes of managers, corporate elites, and broadly defined social movements have appeared, while the "network" has become the basic form of organisational acting. As a result, the spatial shape of the world that was "linked with orthodox manners of the perception of space and environment..." is changing. The same concerns the changing meaning of geographical location and territory as sources of a sovereign's power. Moreover, the concept of "time and space compression" is generated. This in turn forms a challenge that must be faced by the state in order to avoid the marginalisation in global confrontation with new challenges and global "players". The strategy of the Republic of Poland as a reaction to the aforementioned changes, is an example of the author's concept of strategy in the new international space.

Although present in international relations science and the life of the international community, the cultural space and the role of the cultural factor have now become especially significant in the phase of cultural changes, eruption of nationalisms, cultural identity, and ethnical-cultural conflicts in Europe and the world. Nevertheless, one should note that increasing society networking allows for extension of social relations to distances that were difficult to imagine more than a dozen years ago. Contacts of minority groups in various world regions have become ordinary, among others thanks to new global communication networks enabling the extension of social relations to distances difficult to be imagined more than a dozen years ago. Therefore, multiculturalism is becoming a phenomenon that is more and more often present in international life. For example, corporate identity may exist next to national, group, and European identity. National minorities located far from each other (Alaska and New York) become closer.

No modern country can (should) underestimate this factor in its internal and international policy. It may be an important component of diplomacy defined as "soft" and a state's power defined as "soft power". However, for the external world, culture can be the source of a country's power only when it represents universal values, attractive for the external world, instead of provincial, parochial, non-adjustable, and non-transferable ones (Wójcik 2013, 33). Minister Sikorski ascertained the thread of Polish foreign policy for the nearest future in the following words: "Public diplomacy is becoming a more and more important element of conducting our policy. This is the main instrument of socalled soft power, which is nowadays more often and sometimes more efficiently applied than hard power." 


\section{References}

Albrow, M. (1997). The Global Age: State and Society Beyond Modernity. Stanford: Stanford University Press.

Aristotle (2001). 'Politics'. Corpus. Vol. 6.

Baran, B. (1992). Postmodernism. Krakow: Inter Esse.

Barber, B (2013). 'McWorld Rules'. Wprost. Issue 1-6, January 2013, p. 55.

Barber, B. (2013). 'States are Dying, Cities will Save Us'. Gazeta Wyborcza. Issue 12-13, October 2013.

Beck, U. (2005). Power and Anti-power in Global Epoch. Warsaw: Wydawnictwo Naukowe Scholar.

Bieleń, S. (2007). Poland's Geopolitical Position. In: Bieleń, S. ed. Poland in International Relations. Warsaw: Oficyna Wydawnicza ASPRA-JR, p. 20.

Bieleń, S. \& Skrzypek, A. (2012). Geopolitics in Polish-Russian Relations. Warsaw: Oficyna Wydawnicza Aspra.

Castells, M. (2011). The Society of Network. Warsaw: Wydawnictwo Naukowe PWN.

Cohen, S. B. (1963). Geography and Politics in a World Divided. New York: Tandom House.

Dougherty, J. E. \& Pfaltzgraff, R. L. Jr. (1997). Contending Theories of International relations. A Comprehensive Survey. 4th edition. New York: Longman.

Dumała, A. (2010). Epistemological Communities and Lawyer Coalitions - Participants of International Relations “Sui Generis”. In: Pawłowska, A. ed. Non-state Participants of International Relations. Lublin: Wydawnictwo WSPA, p. 181.

Dumała, H. (2012). Transnational Territorial Networks in Europe. Lublin: Wydawnictwo UMCS.

Gałganek, A. (1989). 'Spatial Image of the World in the International Relations Science'. International Affairs. Issue 3/1989, pp. 106-107.

Gałganek, A. (2008). "Westphalia" as a metaphor of the Genesis of the International Relations Science. In: Pietras, M., Marzęda, K. eds. Late Westphalian International System. Lublin: UMCS, p. 53.

Giddens, A. (1990). The Consequences of Modernity. Stanford: Stanford University Press.

Giddens, A. (2008). The Consequences of Modernity. Krakow: Wydawnictwo Uniwersytetu Jagiellońskiego.

Jarczewska-Romaniuk, A. (2005). American Visions of the International Order. In: Kuźniar, R. ed. International Order at the Beginning of 21st Century. Warsaw: Wydawnictwo Uniwersytetu Warszawskiego, p. 227.

Kaufmann, S. J. (1997). 'Fragmentation and Consolidation of International System'. International Organization. Vol. 51, No. 2, p. 174.

Keohane, R. O. \& Nye, J. S. (1977). Power and Interdependence: World Politics in Transition. Boston: Little, Brown and Company.

Kuźniar, R. (2005). Politics and Power. Strategic Studies. Outline of Problems. Warsaw: Wydawnictwo Naukowe Scholar.

Lakomy, M. (2010). 'The Meaning of Cyberspace for Security of Countries at the Beginning of 21st Century'. International Affairs. Issue 4/2010, p. 56. 
Łoś-Nowak, T. (1997). State as a Participant of International Relations. In: Jabłoński, A. W. \& Sobkowiak, L. eds. Studies from the Theory of Politics. Vol. 2. Wrocław: Wydawnictwo Uniwersytetu Wrocławskiego, pp.79-96.

Łoś-Nowak, T. (2005). Realistic Paradigm. Projections of the International Order in the 21st Century. In: Kuźniar, R. ed. International Order at the Beginning of 21st Century. Warsaw: Wydawnictwo Uniwersytetu Warszawskiego, p. 21.

Łoś-Nowak, T. (2009). Post-modern Country: How Much of Tradition, How Much of Post-modernity? In: Lisowska, A. \& Jabłoński, A. W. eds. Visions of a Good State. State in Processes of Transformation. Toruń: Wyd. A. Marszałek, pp. 17-42.

Marzęda, K. (2006). Process of Corporate Globalisation. Bydgoszcz: Oficyna Wydawnicza Branta.

Menkiszak, M. (2005). Russian Visions of the International Order after the Cold War. In: Kuźniar, R. ed. International Order at the Beginning of 21st Century. Warsaw: Wydawnictwo Uniwersytetu Warszawskiego, p. 275. Ministry of Foreign Affairs of Poland (2011). 'Information of the Minister of Foreign Affairs on Assumptions of Poland's Foreign Policy in 2011'. Expose of the Ministers of Foreign Affairs 1990-2011. p. 447.

Ministry of Foreign Affairs of Poland (2011). 'Information of the Minister of Foreign Affairs on Governmental Foreign Policy Presented on 110th Meeting of the Polish Sejm of the Third Term of the Office - 6 September 2001'. Expose of the Ministers of Foreign Affairs 1990-2011. pp. 234-235.

Ministry of Foreign Affairs of Poland (2011). 'Information of the Government on Poland's Foreign Policy in 2003 Presented on 40th Meeting of the Polish Sejm of the Sixth Term of the Office - 22 January 2003'. Expose of the Ministers of Foreign Affairs 1990-2011. p. 273, p. 278.

Ministry of Foreign Affairs of Poland (2011). 'Information of the Minister of Foreign Affairs on Tasks of Poland's Foreign Policy in 2006 Presented on 10th Meeting of the Polish Sejm of the First Term of the Office - 15 February 2006'. Expose of the Ministers of Foreign Affairs 1990-2011. p. 339.

Ministry of Foreign Affairs of Poland (2011). 'Information of the Minister of Foreign Affairs on Assumption of Poland's Foreign Policy in 2011'. Expose of the Ministers of Foreign Affairs 1990-2011. p. 447.

Ministry of Foreign Affairs of Poland (2011). 'Information on Governmental Foreign Policy Presented in the Sejm of the Tenth Term of the Office - 26 April 1990'. Expose of the Ministers of Foreign Affairs 1990-2011. p. 5.

Ministry of Foreign Affairs of Poland (2013). Information of the Minister of Foreign Affairs on Tasks of Poland's Foreign Policy in 2013 [online]. Available at $<$ http://www.msz.gov. $\mathrm{pl}>$.

Moczulski, L. (1999). Geopolitics - Power in Time and Space. Warsaw: Bellona.

Montesquieu, C. L. (1997). The Spirit of the Laws, Kęty: Wydawnictwo Antyk.

Muszyński, J (2001). Megatrends and Politics. Wrocław: ATLA 2.

Nakonieczna, J. (2005). Different World is Possible. In: Kuźniar, R. ed. International Order at the Beginning of 21st Century. Warszawa: Wydawnictwo Uniwersytetu Warszawskiego. 
Niemiec, M. (2008). Interregional and Regional Flows of Direct Foreign Investments. In: Jędrzejczak-Kuliniak, K., Kwieciński, L., Michalski, B. \& Stadtmuller, E. eds. Regionalisation in International Relations. Toruń: Adam Marszałek, p. 128, p. 146.

Panas, E. (2013). Soft Power of Transnational Organisations of Civil Society. Lublin, Doctraol dissertation, not published.

Pietraś, M. (2002). Globalisation as a Process of Change in the International Community. In: Pietraś, M. ed. Faces of Globalisation Processes. Lublin: Wydawnictwo Uniwersytetu Marii Curie-Skłodowskiej, p. 65.

Pogge, T. (2002). World Poverty and Human Rights: Cosmopolitan Responsibilities and Reforms. Cambridge: Polity Press.

Polak, E. (2009). Globalisation and Socio-Economic Diversity. Warsaw: Difin.

Potulski, J. (2010). Geopolitics in the Post-modern World. Częstochowa: Instytut Geopolityki.

Rewizorski, M. (2011). WTO and Global Economy in Time of Globalisation. Koszalin: Wydawnictwo Uczelniane Politechniki Koszalińskiej.

Siemoniak, T. (2013). 'NATO Does Not Threaten Russia, But Also Is Not Afraid Of It'. Gazeta Wyborcza. Issue 14-15, August 2013.

Sprout, H. \& Sprout, M. (1957). 'Environmental factors in the Study of International Politics. The Journal of Conflict Resolution. December 1957, pp. 309-328

Stalder, F. (2012). Manuel Castells, Theory of the Network Society. Krakow: Wydawnictwo Uniwersytetu Jagiellońskiego.

Strange, S. (2003). The Retreat of the State. The Diffusion of Power in the World Economy. Cambridge: Cambridge University Press

Toffler, A. \& Toffler, H. (1996). Creating New Civilisation. Third Wave Politics. Poznań: Zysk I S-ka.

Tymanowski, J. (2009). Neighbouring Eastern Countries in Poland's Security Policy. Torun: Wydawnictwo Adam Marszałek.

Uesseler, R. (2008). War as a Service. How Private Military Companies Destroy Democracy. Warsaw: Wydawnictwo Sic!.

Webber, M. \& Smith, M. (2002). Foreign Policy in a Transformed World. London: Routledge. Wójcik, A. (2013). Culture in the Theory of International Relations. In: Schreiber, H. \& Michałowska, G. eds. Culture in the Theory of International Relations. Vol. 1. Warsaw: Cultural Turn, p. 33.

Wright, Q. (1965). A Study of War. Chicago: Chicago University Press.

Zachara, M. (2012). Global Governance. International Order After the End of US Century. Krakow: Wydawnictwo Uniwersytetu Jagiellońskiego.

Zacher, L. W. (2006). Post-information Society in the Context of Society Evolution and Vision of the Future. In: Habera, L. H. \& Niezgora, M. eds. Information Society: Functional and Dysfunctional Aspects. Krakow: Wydawnictwo Uniwersytetu Jagiellońskiego.

Żukowski, S. (1992). 'Cosmopolitism and Postmodernism vs. Global Order'. Żurawia Papers. Book 13/2009. 